\title{
Local Wisdom in Constructing Students' Ecoliteracy Through Ethnopedagogy and Ecopedagogy
}

\author{
N. Supriatna \\ The Department of Social Studies Education \\ Universitas Pendidikan Indonesia \\ Bandung, INDONESIA \\ nanasup@yahoo.com
}

\begin{abstract}
This paper entails some ideas of how students' ecological intelligence is constructed through ethnopedagogy and ecopedagogy within the process of teaching and learning at schools in Indonesia. This paper is expected to draw provide some inspiration to high school teachers in the area of social sciences, such as Social Studies, History, and Sociology, to explore and make the best use of local wisdom values in order to support students' ecological intelligence. Ethnopedagogy and ecopedagogy were utilized during the process as both are considered as forms of educational approaches and practices. Ethnopedagogy specifically refers to a form of educational approaches and practices based on local wisdom. In ecopedagogy, however, such approaches and practices are not only specifically based on local wisdom, but also on various aspects directed to gain understanding, awareness, and life skills corresponding to environmental preservation matters (Kahn, 2008). In the author's view, ecological intelligence, as an aptitude to understand, realize, and actualize the significance of living in harmony with the nature, can be supported by both pedagogical forms. This paper will put forward the local wisdom of Sundanese traditional community in West Java Province consisted in the folklores especially related to the methods of preserving forest's natural condition, water source, and local food consumption. Such local wisdom is promoted and developed as learning materials to provide students with ecological intelligence related to understanding, awareness, and competence for significant preservation of forest and water resource. Local wisdom is also explored and integrated into the curriculum to construct students' awareness as green consumers or those favoring local products over the global ones.
\end{abstract}

Keywords- ethnopedagogy, ecopedagogy, ecoliteracy, local wisdom, teaching social studies.

\section{INTRODUCTION}

Through both pedagogical methods mentioned above, students' ecological intelligence on environmental conservation can be developed in the learning process. Local wisdom can be explored by comprising folklore into learning process. In developing the process, teachers may refer to sources derived from the local wisdom of traditional community. This condition becomes substantial as students in Indonesia, similar to others in some developing countries (Mungmachon, 2012), have been influenced by globalization run by free market economic system. Moreover, students' attitude on global product consumption reflects not only their consumptive behavior, but also their delicacy to resist global influence. Consumptive behavior is a negative effect of new imperialism supported by capitalism and free market economy (Harvey, 2013, and Supriatna, 2015). To deal with globalization movement, students need to be empowered by implementing ecopedagogical and ethnopedagogical approaches that make use of local wisdom values in folklore for classroom learning activities.

Numerous tribes in Indonesia have traditions entailing local wisdom. There are many definitions of local wisdom, but generally it is described as verified consideration, awareness, action, and belief implemented in the society for many generations and used as life basis/principles. According to Keraf (2006), local wisdom is any forms of knowledge, belief, understanding, or conception and tradition or ethics directing human behavior in ecological community. Koentjaraningrat (1990) further mentioned that local wisdom is a view of life, knowledge, and a variety of life strategies actualized in local community activities to cope with various problems in fulfilling their needs in all aspects of life, such as religion, belief, science and technology, social organization, economy, language, and arts. Specifically, local wisdom examined in this paper is related to the concept of sustainability or actions for living in harmony with the nature as implemented by traditional community among Indonesian ethnic groups.

This paper puts forward the description of local wisdom in the context of ecopedagogy and ethnopedagogy as academic approaches to encounter global issues. Local wisdom can be used as an academic means to respond consumerism culture, forest destruction, lack of water and food supply, depletion of ozone layers, and others. Local wisdom becomes one of social science learning resources at schools to build students' ecological intelligence for saving water, becoming green consumer, saving energy in daily life, recycling, reducing plastic use, and more.

In dealing with global issues on forest destruction, traditional community in many countries holding onto local wisdom is able to conserve the eternity of the forest. A study from Chaipar, Sakolnakorn and Naipinit (2003) in Thailand, for instance, suggests that local community with its local wisdom is able to protect the environment. It has also been 
reported in the results of World Resource Institute's research (2014), entitled Securing Right, Combating Climate Change, that the samples of traditional community from 14 countries in Africa, Latin America, and Asia indicate that they are able to control deforestation. Conversely, the control of forest by the government or private sector (global corporation) unfortunately leads to the acceleration of deforestation. Therefore, traditional values protected and inherited over generations to conserve the nature can be a solution to resolve global warming. Those values can be used by social science teacher as learning materials to construct students' ecological intelligence.

Below is an analysis on local wisdom in West Java related to that in retaining forest conservation, protecting water source, consuming local food, and preparing future food stock. Local wisdom that is analyzed academically is ethnopedagogy as it becomes one of learning resources at school.

\section{LOCAL WISDOM OF LEUWEUNG LARANGAN (PROHIBITION FOREST) TO AVOID DEFOREATATION}

Some areas in Indonesia have local wisdom to protect the forest. Dayak community in South Borneo, for example, usually pray before they cut a tree. It is intended to prevent problems with creatures protecting the forest (Fahrianoor, 2013). In Sunda community in West Java, forest conservation is reflected on their system of belief as the local wisdom of leuweung larangan (prohibition forest). This local wisdom is hold and implemented over generations by Sunda community, those living in the area of West Java and Banten provinces. Some groups of Sunda communities living in rural areas believe in myths on leuweung or a forest prohibited to be cut down or even passed in by local people. The myth of the forest is anthropologically a part of folklore living from one generation to another. In the myth, the community believes the forest is protected or occupied by spirits that may threat people when disturbed. It can be due to people penetrating the area, taking some wood or plants, hunting animals, or closing water source of the forest. As a result, to prevent the risk of disturbance from "the guardian creature", people are not allowed to go in or break the rules. Folklore as a cosmology of traditional community is inherited from former generations and still implemented until today.

Halimun Mountain ranges surrounding the areas of Bogor regency of West Java province and Lebak and Rangkasbitung regencies of Banten province have a concept of leuweung larangan named as leuweung titipan (Adimihardja, K 1992: 120-121, Iskandar J, 2011). The local wisdom is actualized by dividing forest areas for human benefit sources and areas of prohibition. Leuweung titipan is a sacred forest that is not allowed to be exploited by anyone, except those permitted by sesepun girang (a traditional leader) believed by local people of having the ability to receive wangsit (messages) from their ancestors. With that system of belief, leuweung titipan is protected appropriately based on local belief, so that the forest will support people's life.

Folklores of leuweung larangan and leuweung titipan are full of natural conservation values. Rationally, if the forest is damaged, human life can be threatened. The threat is from the damages. For instance, people will not have water flowing from the water source in the forest if trees or plants are cut down. Water as the source of life is an important element to support all creatures' life. Various animals living in the forest are parts of the ecosystem. Forest and animals are in a food chain not to be broken by humans. As an illustration, if the number of mice decreases - hunted by humans - snakes as their predators will lose their food. The hungry snakes may go out of the forest for food or prey, and they may threat people at the residence. On the contrary, snakes at the forest must not be bothered since they may be useful for people to catch mice as pests of rice. The myth about spirits in leuweung larangan is a type of local wisdom living over generations to conserve the forest. The system of belief of traditional community in West Java and Banten incorporating the myth is a form of ecological intelligence to actualize a harmony life with the nature. It has been proven that forests in other areas possessing similar leuweung larangan or leuweung titipan are protected well and the water flow still run from those areas.

Local wisdom may prevent deforestation. In areas without leuweung larangan concept, forests are still being destroyed and exploited. Forest in West Java has been cleared since the era of Mataram Kingdom, Dutch colonialization, and until today after the Independence Day. In the era of Mataram Kingdom, forest exploitation was intended for providing residential area. The term of ngababakan is an activity to open new land for the community to gather in a particular area that will then become a residential area (Ekadjati, 1984). Since the land was spacious and the number of people was low, there was no environmental problem occurring at that time. However, the transformation of forest into residential and agricultural area was started and continued until today. The exploitation of forest also occurred as West Java was a part of Netherland Indies in the colonial era. During cultuur stelsel (1830-1870), the opening of new land was more intensive due to horticultural matters. Heterogenic forest turned out to be homogeny forest or precisely horticultural area, such as rubber, coffee, quinine, tea, and more. Those commodities were favorites in the international market. Even though forced cultivation system was terminated after 1870 , new plantations have still been opened particularly since the Laws of Agrarian Affairs started to prevail in 1870 that allows global corporation to open cultivation lands. Since then, such transformation has been more intensive. Thus, since Indonesia entered liberal economy era, forest space has decreased and a range of natural resources started to be exploited. For instance, based on the data from the Department of Forestry of West Java the space of forest in the province declined $17,7 \%$ in 2003-2009 because of the construction of housing infrastructure and agricultural expansion (Dephut, 2010). As the province with the highest population and the widest industrial area in Indonesia, West Java is considered to have a relatively huge environmental problem.

From the time of the independence of Indonesia, government policy to improve people's prosperity has been dealing with intensive exploitation of natural resources and forest area as the focus of national development. Consequently, forest area has shrunk, especially since the New Order era that widely expanded the investment of foreign capital in various sectors, such as mining, horticulture, and industry that require a 
large range of land. Indonesia as one of the centers of world lung has an extensive deforestation problem. Within 32 years, from 1965 to 1997, Indonesia lost 20 million ha of forest. The acceleration of deforestation increased in 1997-2000. Within three years, Indonesia lost 5 million ha of its tropical forest (Supriatna, J, 2008).

Currently, modernization and liberal economy overturn not only local wisdom but also traditional community that has significant roles in conserving the existence of forest. Many mass media in March 2015 reported the loss of lives of a number of Anak Dalam tribe members in Jambi due to the shortage of food supply, and it also suggests that traditional community's existence is threatened by globalization. Forest as the ecosystem and habitat of Orang Rimba, Orang Batin, and some other traditional communities is getting narrower due to agricultural expansion, mainly for palm plantation, mining, motorway access and some other aspects to fulfill the commodity of free market economy. Teuku Kemal Pasha (2015) called the threat over the existence of traditional communities in many areas in Indonesia due to forest exploitation as civilization tragedy. Protection for tradition communities with their local wisdom to conserve the forest has become a crucial matter nowadays. The local widom of leuweung larangan and leuweung titipan to prevent or hinder deforestation needs to be sustained. The future of world community, especially in Indonesia, is now dealing with unsustainability problem as some resources are damaged due to paradigm of anthropocentrism.

To build students' ecological intelligence in social science learning, local wisdom can be used as learning media and resource. The local wisdom of leuweung larangan and leuweung titipan should be a compulsory input at schools in West Java and Banten areas. That local wisdom can be integrated into ongoing curriculum and adjusted to students' situation and condition and school culture. The learning process can be conducted in the classrooms using some media, such as films, photos, and audio recordings or printed materials consisting of local wisdom materials and data on deforestation in some areas. The learning process can also be conducted outside the class by having a field trip to a particular area with folklore and local wisdom with feasible distance and facilities. Such field trip should be a part of curricular activities appropriate to school curriculum. With such activities, students will gain knowledge, awareness, and competence to implement their ecological intelligence in daily life, for example, ecological intelligence in planting and maintaining plants and trees at school or at home.

To deal with and handle deforestation, social science learning can provide students with the ability to reduce, reuse, and recycle items produced from forest cultivation process. Paper, wrapping cardboard, and tissue paper are examples of wood products processed from the forest and consumed by modern society. For example, students are supplied with understanding, awareness, and skill to reduce, reuse, and recycle papers. Each sheet of paper used entails a number of woods cut down from the forest. More use of papers leads to wider deforestation and subsequently faster change and warmer temperature on earth's surface or global warming. With foundation on local wisdom of leuweung larangan, urban students interested in Asian culinary can be advised to use reusable chopstick rather than single-use wooden chopstick. Schools can also campaign the use of kerchief instead of tissue papers. If students are accustomed to consume forest-resourced products, especially those in urban areas, reducing method can be an ingenious method for an environmentally-friendly lifestyle.

\section{THE LOCAL WISDOM OF BABASAN SUNDA TO TACKLE CONSUMPTIVE CULTURE}

Environmental damages and the shortage of natural resources on earth are caused by higher consumption of modern society over natural-resource-processed products. Sunda community has some babasan or proverbs conveying the importance of today's safe consumption for tomorrow's supply. A proverb of saeutik mahi loba nyesa means a little must be sufficient and more must remain for the next day. The expression of seutik mahi or a little must be sufficient suggests a value of living a simple life that would be mahi (adequate) even with a little resource (saeutik) and no need to spare more. In addition, loba nyesa or more must remain expression implies a view for future preparation with present stock. With such proverbs, Sunda community in agricultural areas realizes that as they have sufficient food supply for one day, they should not exhaust the whole supply, but they should leave some amount for the next day. This expression entails a local wisdom over the consumption of natural resource and the importance of saving and future planning.

Future preparation as a local wisdom value is reflected on the tradition of agricultural Sunda community to store food or crops. People in some traditional communities, such as Kuta Village in Ciamis, Kampung Naga in Garut and Halimun Mountain areas (covering Bogor, Lebak and Pandeglang regencies), and Traditional Village of Baduy Banten province, as examined by Adimihardja (1992), have leuit or lumbung or rice barn to store their crops. Leuit functioned as a warehouse is used to store food supply in order to prepare for paceklik or dry season in which people cannot grow their plants. In paceklik, farmer cannot plant and to prepare for the lack of food supply during the season, people have to collect and store their crops. Leuit can be built for individual or for a group of people. Besides leuit, traditional community of Sunda also stores their food supply in a particular place named goah. In goah, people mainly store rice as their staple food and some other supplies.

It turned out that babasan and food storage system of agricultural Sunda community signify a futuristic view of consumption pattern and future planning. Some thesis about agricultural community in Java as written by Western anthropologists, such as Cliford Geerz (1971) suggesting subsistent culture or agricultural culture that gives precedence to today's needs and ignores future prospect, need to be revised. The concept of involution or a static condition in farming community is considered to constrain development. Nevertheless, involution can also be perceived positively as the static condition suggests the agricultural environment is well protected. In agricultural Sunda community, such babasan and food storage system indicate the opposite of subsistent culture. 
The culture of one-day food consumption is actually more familiar among industrial communities as a product of modernism. In positivistic view, a change has to be made through performance. Performance leads to the use available potentials, including natural resource potential. Processing natural resource means increasing production and consumption. All those aspects will influence the transformation positively identified on growth rate and increasing income or capital. The mechanism of capitalistic economy is exploitation over natural resources as the consequence of demanding transformation and development. In contrast, low-pace changes or even a stagnant financial condition of traditional agricultural community can be relevant for the conservation of the nature. From the aspect of babasan and food storage system, traditional community Sunda shows a local wisdom relevant to the concept of sustainability, asserting adequate consumption today without overexploitation of natural resources.

Java community, on the other hand, has an expression of sugih tanpa bandha meaning living in prosperity without material luxury. This expression suggests that someone may live a prosperous life, but it is not measured by excessive materials. Life is not always a matter of possessions of wealth. Building relation with other people and environment, including natural environment, in their surrounding can be a point of prosperity. A philosophy promoted by Raden Mas Pandji Sokrokartono (passed away in 1952), a brother of the woman emancipation figure, R.A. Kartini, denotes the significance of living in modesty without any greed or even materialism attitude (bandha).

Such local wisdom value can be a lesson in the subject of social sciences to educate students as a part of modern society. One of the characteristics of modern society is consuming industrial products derived from natural-resource based materials. The more they consume the products, the more they exploit natural resource. The local wisdom of traditional community of Sunda, Java, and more can a moral lesson for modern society in Indonesia about the importance of being green consumers, those having knowledge, awareness, and decision to select and consume environmentally friendly products (Goleman, 2009) and those taking lesson local wisdom values.

Modern society is now dealing with challenges to demonstrate its existence as human. To actualize themselves, people need to decide on self-existence as a being through mode of being or mode of having concepts. Mode of being concept is upheld by a German philosopher, Martin Heideger (1889-1976), over human existence. Heideger considered that human existence does not rely on his subjective perspective on reality in the real world. Subjective view in human thoughts about something in the reality of life may not as actual as the reality itself. In brief, Heideger's mode of being concept implies that human existence is not always determined by material matters or possession (Stanford Encyclopedia of Philosophy, 2011). Hence, according to Heideger's point of view, the existence of modern people determined by material possession (mode of having) becomes irrelevant. As society is affected by consumerism due to industrialization, the essence of their humanity is compromised as their self-measurement (self-existence) is determined by materials possession (mode of having). That mode of having is fulfilled by various methods, including increasing exploitation of natural resource.

By information-and-technology-based packaging in marketing products, consumers frequently become the objects of hegemony of dominant technology, information, producers, and ideology behind industrialization. Herbert Marcuse (1964), one of supporters of critical theory of Frankfurt School, appointed consumptive society as society without opposition, or a society non-autonomous and reluctant to consumerism. In his book, One-Dimensional Man (1964), Marcuse mentioned consumerism society as a society incapable to resist various products that may mislead them:

".......the system we live in may claim to be democratic, but it is actually authoritarian in that a few individuals dictate our perception of freedom by only allowing us choices to buy for happiness. In the state of "unfreedom" consumers act irrationally by working more than they are required to in order to fulfill actual basic needs, by ignoring the psychologically destructive effects, by ignoring the waste and environmental damage it causes, and by searching for social connection through material items.

If human existence in traditional community is based on values contained in the local wisdom, the existence of modern society is reflected on what they consume. Furthermore, they do not realize whether their consumption is based on their needs or their desire. To Marcuse, modern industrial society has been controlled by hegemony holders, such as producers, media owner, and information collectors, so that what they consume is a form of false needs, or unnecessary demands. Moreover, Marcuse asserted:

It is more rational in the sense that the creation of new products, calling for the disposal of old products, fuels the economy and encourages the need to work more and to by more. An individual loses his or her humanity and become a tool in the industrial machine and a cog in the consumers machine. Additionally, advertising sustains consumerism, which disintegrates societal demeanor, delivered in bulk and informing the masses that happiness can be bought, an idea that is psychologically damaging".

In ecopedagogical context, society movement is necessary to impede consumerism and prevent exploitation of natural resources. In this case, ecopedagogy can be considered as an anti-consumerism movement intended to prevent or reduce consumerism extent. The reduction of consumerism may positively affect the exploitation of resources of the planet. Consumption reduction will decrease emission or waste that may contaminate the environment. Marcuse said:

There are other alternatives to counter life style. Anticonsumerism is a lifestyle that demotes any unnecessary consumption, as well as unnecessary work, waste, etc. But even this alternative is complicated by the extreme interpretation of advertising and commodification because everything is commodity, even those things that are actual needs".

Social science learning can use the principles of a simple life, environmental conservation, and futuristic view from traditional community as implemented and based on local 
wisdom values. In the context of ecopedagogy, this idea becomes crucial considering the tendency of urban students as a part of consumptive society as mentioned by Marcuse. Students are not able to differentiate their needs and their desire. Their consumption method imitates what is portrayed in the advertisement of products. For example, students prefer to use chips as snack packaged with plastic or paper. Meanwhile, only a few of them are willing to consume eggs as daily meals. This condition occurred as there are more advertisements of the snack than those - even if they exist - of the importance of egg consumption. As the "ads victim", it is no longer peculiar if students prefer to consume junk food or fast food with international brand - compared to organic fibrous food made at home. Referring to Goleman's analysis (2009), foods processed with flavor enhancer and preservatives may harm consumers' health and plastic or paper package will increase emission or waste that may contaminate the environment.

Below is a table presenting consumption pattern of urban students and ecopedagogical aspects to encounter consumerism in social science learning process as adjusted to students' level of education.

TABLE I. CONSUMPTION PATTERN AND ECOPEDAGOGICAL ASPECTS

\begin{tabular}{|c|c|c|}
\hline No & $\begin{array}{l}\text { Students' } \\
\text { Consumerism }\end{array}$ & Ecopedagogy-Based Social Science Learning \\
\hline 1 & $\begin{array}{l}\text { Consuming } \\
\text { instant food }\end{array}$ & $\begin{array}{l}\text { Introducing a range of organic foods as consumed } \\
\text { by traditional community in the materials of } \\
\text { natural resources } \\
\text { Bringing lunch box and drinking bottle } \\
\text { Setting school canteen that provides } \\
\text { environmentally friendly foods }\end{array}$ \\
\hline 2. & $\begin{array}{l}\text { Frequently } \\
\text { altering writing } \\
\text { utensils, papers, } \\
\text { and preference to } \\
\text { a particular brand }\end{array}$ & $\begin{array}{l}\text { Introducing the concept of values in use, } \\
\text { functionality, and benefit of particular items apart } \\
\text { from their brand or image. It can be related to } \\
\text { materials on production, distribution, and } \\
\text { consumption } \\
\text { Using go green labeled products } \\
\text { Learning from the concept of saeutik mahi loba } \\
\text { nyesa or sugih tanpa bandha some others from } \\
\text { traditional community }\end{array}$ \\
\hline 3 & $\begin{array}{l}\text { Habitually } \\
\text { requesting extra } \\
\text { money }\end{array}$ & $\begin{array}{l}\text { Telling the importance of discussion about } \\
\text { income and its source with parents } \\
\text { Appreciating profession and working values } \\
\text { Respecting process, not only the result }\end{array}$ \\
\hline 4 & $\begin{array}{l}\text { Expecting } \\
\text { consumptive } \\
\text { products } \\
\text { advertised }\end{array}$ & $\begin{array}{l}\text { Developing the concept of reduce, reuse, and } \\
\text { recycle on consumptive products } \\
\text { Teaching skills for selecting and processing } \\
\text { information (especially on product ads) } \\
\text { Learning on making decision based on priority } \\
\text { scale }\end{array}$ \\
\hline 6 & $\begin{array}{l}\text { Habitually } \\
\text { gathering and } \\
\text { shopping in } \\
\text { shopping centers } \\
\text { or fast food } \\
\text { restaurant }\end{array}$ & $\begin{array}{l}\text { Visiting traditional village or playing movies on } \\
\text { simple lifestyle of traditional community in some } \\
\text { areas in Indonesia } \\
\text { Modeling simple life of successful figures } \\
\text { Introducing the concept of self-actualization on } \\
\text { achievement, not materialsm }\end{array}$ \\
\hline 7 & $\begin{array}{l}\text { Expecting to } \\
\text { have personal } \\
\text { vehicles like } \\
\text { their parents, for } \\
\text { school } \\
\text { transportation }\end{array}$ & $\begin{array}{l}\text { Introducing and using public transport to go to } \\
\text { school or using environmentally friendly } \\
\text { transport, like bicycle } \\
\text { Doing student activities (such as playing at front } \\
\text { yard and sand box) without footwear at school } \\
\text { yard to touch the ground as an earthing activity } \\
\text { for improving body metabolism }\end{array}$ \\
\hline
\end{tabular}


same initial denoting those places as kabuyutan or the initiation of a residence with constantly available source of water, forest, and rocks. In each kabuyutan, the water source is always perceived sacred as people consider that water will give life to generation today and in the future.

Besides its similarity to head, another analogy of vital parts of body for water source is the navel, the center of life. Sunda community in the past called water source as sanghyang udel or the holy navel. It is also called sanghyang pertiwi the spring comes out from inside of the earth. Such labeling process has become a part of micro and macrocosm attachment between themselves and the earth where they live. As a system of belief, they need to protect he river, the mountain where the forest exists, and the rocks. It is believed that decent relation between humans and nature will have an effect on their life. On the contrary, ignoring natural matters will harm their life. For that reason, the community should be obedient with prohibition called pamali because from their real experience, every violation over pamali will impair them. That belief is reflected in babasan or proverbs portraying the relation of human and nature.

There are some babasan of Sunda related to water and composed of values on the importance of conserving water source. That babasan is also related to forest as the place to store and flow ground water. It also asserts the significance of conserving forest as water storage, so that forest must not be destroyed. Babasan of leuweung rusak, cai beak, rakyat balangsak indicates a local wisdom value about the importance of preserving forest as the source of water. That proverb suggests if the forest is damaged, water will run out and people will suffer. Similar tone of forest conservation is also reflected in babasan of leuweung kaian, gawir awian, sampalan kebonan, legok balongan. It means that forest must have trees, inclined hill must have bamboos, landscape must be planted, and the lowest ground (legok or valey) must be water area. Water will flow to legok and therefore it can be used for farming fish in balong (a pond). Another babasan is gunung teu menang dilebur, legok teu meunang dirusak. It says that mountain must not be exploited and lower ground must not be damaged. People exploring forest in many areas in Indonesia to open new land by burning the forest including living creatures inside it for building plantation or others have to learn more from that local wisdom.

The local wisdom for protecting water source from upriver refers to kiruh ti girang kiruh ka hilir. This proverb tells if the upriver source of water is dirty, the same dirt will go downstream. Holding on that babasan, the community believes that if the upriver is protected well, the flowing water will support lives of people along the current. Such wisdom is a valuable lesson for the community in conserving the environment as most part of the upriver area and their current in West Java has been highly contaminated.

The transformation of agricultural society into industrial society in West Java is the fastest among that in other areas in Indonesia. As the closest province to the capital (Jakarta), West Java has serious responsibility to conserve its environment. The appealing transformation into industrial area considered to be economically more promising has encouraged functional modification of agricultural ground for industrial, residential, transportation, and some other purposes. For example, the current of Citarum river flowing from Bandung has been extensively exploited. That area has turned out to be residential, industrial, commercial areas, and more. Some people living at upriver area irresponsibly throw waste to the river. Accordingly, Citarum river as the basic source of water for at least 20 million of people in West Java and Jakarta has become the most contaminated river in Indonesia as polluted by abundant industrial and domestic waste. Each year, Citarum river overflows and causes flood especially at the southern part of Bandung. Today, ecopedagogy as a step to return to local wisdom for protecting water source, forest and river can be either an academic program or even a political move to renew anthropocentric view that put higher priority on economy over environmental conservation.

If the traditional community can still depend on water source its well-protected spring, now industrial society become highly depending on bottled water produced by private producer. The law Number 7 of 2004 allows the private sectors to manage the water source and transform that affordable natural resource into one of the commercial components of industrial society households. About 80 percent of urban community water consumption relies on water produced by private sectors. The data reported, as cited from several sources, assert that bottled water products reached 20.3 billion liters in 2013 and increased into 23.9 billion liters in 2014. What is worse is that some bottled water producers are global corporations centered in England and France. At this time, the common needs of many people in Indonesia - in the case of water consumption - depend on neoliberal economic mechanism. The local wisdom of traditional community for maintaining water spring is challenged to be re-explored and implemented as a learning resource of social science at school.

The discontinuity of the Law Number 7 of 2004 by Constitutional Court in March 2015 (Kompas daily newspaper, March 13, 2015) authorizes the government to implement the mandate of the Law of 1945 of article 33 asserting: land, water, and natural resources they contained are managed by the government and utilized at most for the prosperity of the country. It is expected that under the government's management, water can necessarily support people's life as performed by traditional community holding on local wisdom values.

Social science learning at school must be able to respond environmental problems related to water resource. Today, local wisdom is endangered by modernization. Students' attitude at school portrays the attitude of modern industrial society that highly depends on bottled water. Bottled water producers pay much attention on hygiene and plastic packages. The emission from plastic packages may harm the environment. Thousands of plastic waste in urban areas is one of the sources of environmental pollution and damages that is difficult to be handled by the society and city administrative.

The high consumption of bottled water from industrial process indicates deficient management of water resource by community and government. Dues to over exploitation on natural resource, the water source from springs in rural areas 
has disappeared one by one. Because of high intensity of ground water pulled for household and industry in urban areas, ground water resource has become lower. To illustrate this, in Bandung, ground water has decreased as the result of low water absorption as most of water absorption areas are concealed by construction. In Bandung, in 1980-1990, there were 32 drilled wells containing up to 400 liters of water per second. But recently, the amount of water from the depth of 100-150 m may only be 200 liters per second. Similarly, Cileunca Lake once potentially contained 1400 millimeter of water per second, but in 2014, the amount decreased until 600 millimeter per second as reported by Kompas daily newspaper, March 9, 2015.

Local wisdom entailing enclosed relation between society and water source can be revived within social science learning. Teaching over the local wisdom of Sunda and some similar values from several ethnic groups in Indonesia is one of approaches in ecopedagogy. Learning process is conducted not only in the class, but also outside. To develop ecological intelligence, outdoor learning is better as it will bring students closer to the nature. The result of study from Lloyd A. and Gray T. (2014) suggests that outdoor learning can encourage students to perform pro-environmental behavior. In addition, Rafferty, J. and Laird, S. G. (2013) study shows that outdoor observation activity could improve students' understanding of nature.

To build ecological intelligence, the preparation of school infrastructure to provide sources of water is also important. Some ecological actions to be developed at schools are listed below:

1. Letting school yard opened to absorb rain water. This method can increase ground water supply,

2. Providing more absorption wells surrounding school to flow rain water into the ground,

3. Storing rain water and processing it to be drinking water for school community,

4. Developing ecopedagogical movement by consuming water processed at school without relying on bottled water produced by global corporation,

5. Schools in rural area can rebuild ponds for fish farming and protecting water source at the same time,

6. Enforcing green school concept or adiwiyata school, which upholds the concept of sustainability using available local potential (water resource).

With available infrastructure, social science learning can develop students' ecological intelligence using following

To build students' ecological intelligence, social science teacher can use curriculum documents available as well as for dialogue connected to social experience and issues encountered by students. Social science materials in elementary school, junior high school, and senior high school can be processed and improved for developing ecological intelligence. Teacher positioned as curriculum developer and students as learners that may construct their learning experience are the best means to develop learning through a variety of learning strategies. The local wisdom for protecting water resource is used to achieve the goal.

strategies in Table II.

TABLE II. DEVELOPING STUDENTS' ECOLITERACY

\begin{tabular}{|c|c|c|}
\hline No & $\begin{array}{l}\text { Students' attitude } \text { on } \\
\text { water consumption and } \\
\text { resource }\end{array}$ & $\begin{array}{l}\text { Ecopedagogy-based strategy for social } \\
\text { science learning }\end{array}$ \\
\hline 1 & $\begin{array}{l}\text { Shortage of water } \\
\text { resource }\end{array}$ & $\begin{array}{l}\text { Exploring community local wisdom } \\
\text { from written references for protecting } \\
\text { water resource } \\
\text { Visiting the location of nearest } \\
\text { traditional community to learn local } \\
\text { wisdom for protecting water resource }\end{array}$ \\
\hline 2. & $\begin{array}{l}\text { Excessive consumption } \\
\text { of bottled water }\end{array}$ & $\begin{array}{l}\text { Encouraging students to bring drinking } \\
\text { bottle from home } \\
\text { Reducing the consumption of drinks } \\
\text { processed with preservatives, artificial } \\
\text { flavoring and sweetener over mineral } \\
\text { water }\end{array}$ \\
\hline 3 & $\begin{array}{l}\text { Ecological intelligence } \\
\text { in saving water in the } \\
\text { toilet }\end{array}$ & $\begin{array}{l}\text { Developing the habit of using water in } \\
\text { the toilet wisely, like turning off water } \\
\text { tap after use } \\
\text { Encouraging students to flush waste with } \\
\text { adequate water }\end{array}$ \\
\hline 4. & $\begin{array}{l}\text { Using recycled water for } \\
\text { plants at school }\end{array}$ & $\begin{array}{l}\text { Encouraging students to water and grow } \\
\text { plants using recycled water }\end{array}$ \\
\hline 5 & Consuming local water & $\begin{array}{l}\text { Encouraging students to consume water } \\
\text { at school or water processed by local } \\
\text { producers }\end{array}$ \\
\hline
\end{tabular}

\section{REFERENCES}

[1] A. Jupri, Z. Kusuma, K. Hidayat K dan M. Purnomo, "The Efforts of Spring Conservation through Local Wisdom at Lingsar, West Lombok, West Nusa Tenggara, Indonesia", in Journal of Environment and Earth Science, Vol.5, No.6, 2015 , p. 98, Online: www.iiste.org.

[2] A. Lloyd, and T. Gray, "Place-based outdoor learning and environmental sustainability within Australian Primary School", in The Journal of Sustainability Education, Vol. 1, October 2014.

[3] C. Geerz, Agrarian Involution. Ohio: Barkeley, 1971.

[4] Departemen Kehutanan, Provinsi Jawa Barat. Bandung: Dephut, 2010.

[5] D. Goleman, Kecerdasan Ekologis, Mengungkap Rahasia dibalik Produk-produk yang Kita Beli. Jakarta: Gramedia, 2009.

[6] D. Harvey, The New Imperialism. New York: Oxford University Press, 2013.

[7] E.S. Ekadjati, Masyarakat Sunda dan Kebudayaanny. Jakarta: Giri Mukti Pustaka, 1984.

[8] Fahrianoor, at all, "The Practice of Local Wisdom of Dayak People in Forest Conservation in South Kalimantan", in Indonesian Journal of Wetlands Environmental Management, Vol. 1, No. 1, September 2013.

[9] H. Marcuse, One-Dimentional Man, Studies in the Ideology of Advanced Industrial Society, 1964, Online: www.marcuse.org/herbert/pubs/64onedim /odmcontents.html.

[10] J. Iskandar, Agroekosistem Orang Sunda. Bandung: Kiblat, 2012.

[11] J. Rafferty and S.G. Laird, "Children's Observations of Place-Based Environmental Education: Projects Worlds apart Highlight Education for Sustainability Inherent in Many Programs", in The Journal of Sustainability Education, Spring 2013.

[12] J. Sumardjo, Sunda, Pola Rasionalitas Budaya. Bandung: Kelir, 2011.

[13] J. Supriatna, Melestarikan Alam Indonesia. Jakarta: Yayasan Obor, 2008. 
[14] K. Adimihardja, Kasepuhan yang Tumbuh di atas yang Luruh, Pengelolaan Lingkungan Secara Tradisional di Kawasan Gunung Halimun Jawa Barat. Bandung: Tarsito, 1992.

[15] Koentjaraningrat, Kebudayaan, Mentalitas dan Pembangunan. Jakarta: PT Gramedia, 1990.

[16] Kompas, "Kontrak Air Direnegosiasi Pihak Swasta Tak Boleh Kuasai Sumber Air Bersih", in Koran Kompas, 13 Maret 2015.

[17] N. Supriatna, "Confronting Consumerism as a New Imperialism: Students' Narratives in the Indonesian History Learning”, [conference paper at the International Conference of the Commemorating of Asian and African Conference, Bandung, July 2015].

[18] R. Kahn, "From Education for Sustainable Development to Ecopedagogy: Sustaining Capitalism or Sustaining Life?", in Green Theory \& Praxis: The Journal of Ecopedagogy, Vol. 4, No. 1, 2008.

[19] S. Keraf, Etika Lingkungan. Gramedia: Jakarta, 2006.

[20] R. Mungmachon, "Knowledge and Local Wisdom: Community Treasure", in International Journal of Humanities and Social Science, Vol. 2 No. 13, July 2012.

[21] Stanford Encyclopedia of Philosophy, Martin Heideger. Online: www.plato.stanford.edu/entries/heidegger/3BeiWor, 2011.

[22] Sumarni "Local Wisdom of Osing People in Conserving Water Resources", in International Journal of Indonesian Society and Culture, Vol. 7 No 1, 2015.

[23] W. Chaipar, Sakolnakorn, TPN, and A. Naipinit, "Local Wisdom in the Environmental Management of a Community: Analysis of Local Knowledge in Tha Pong Village, Thailand", in Journal of Sustainable Development, Vol. 6, No. 8, Canada: Canadian Center of Science and Education, 2003.

[24] World Resource Institute, Securing Right, Combating Climate Change, 2014, online: http://www.wri.org/sites/default/files/securingrights-fullreport-english.pdf\&prev=search. 